\title{
A PHARMACOEPIDEMIOLOGICAL STUDY ON THE SIDE EFFECTS OF INDAPAMIDE
}

\author{
CRISTINA-MARIA GAVRILESCU ${ }^{1 *}$, ANDREI CERNOMAZ ${ }^{2 *}$, RADU CRISAN-DABIJA $^{2 *}$, \\ RADUCU IONUT POPESCU ${ }^{3}$, ROXANA MIHAELA BARBU $^{3}$, DANIELA BOISTEANU $^{2}$, \\ OANA-ELENA ROHOZNEANU ${ }^{4}$, BEATRICE MAHLER $^{5}$ \\ ${ }^{1}$ Medical Department I, “Grigore T. Popa” University of Medicine and Pharmacy, Iași, Romania \\ ${ }^{2}$ Medical Department III, "Grigore T. Popa” University of Medicine and Pharmacy, Iași, Romania \\ ${ }^{3}$ Department of Morpho-Functional Sciences II, "Grigore T. Popa" University of Medicine and Pharmacy, Iași, Romania \\ ${ }^{4}$ Clinic of Pulmonary Diseases Iași, Clinical Hospital of Pneumophtisiology Iași, Romania \\ 5 "Carol Davila” University of Medicine and Pharmacy, Bucharest, Romania
}

*corresponding author: crisanradu@gmail.com

${ }^{*}$ Authors with equal contribution.

Manuscript received: February 2020

\begin{abstract}
Although thiazide-like diuretics were initially known to have little or no metabolic side-effects, some later evidence showed some of their adverse reactions. We aimed to survey their side-effects in long term administration. We conducted a prospective pharmacovigilance study on the metabolic side-effects of indapamide in the $\mathrm{V}^{\text {th }}$ Internal Medicine Clinic Iași, Romania, between 2016 and 2018. Thirty hypertensive patients were monitored regarding glycaemia, uricemia and kaliemia before starting indapamide administration (T0), after at least three months of administration (T1) and after at least some other three months of withdrawal (T2). A significant increase of glycaemia and uricemia appeared after three months of administration of indapamide, which disappeared in most of the cases after stopping the treatment. A significant decrease of kaliemia was also noted under treatment and it was reversible after stopping indapamide. The incrimination of indapamide in producing hyperglycaemia, hyperuricemia or hypokalaemia was certain or probable in eight cases and possible in five cases according to the WHO-UMC (2010) algorithm for causality assessment. Thiazide-like diuretics may expose to the same metabolic risks as thiazide-type diuretics. Precautious administration in case of already present hypokalaemia could be protective. Larger studies are needed in order to define the dose, the period of administration or other associated factors that could expose to an increased risk of side-effects.
\end{abstract}

\section{Rezumat}

Deși initial se considera că diureticele de tip tiazidic prezintă efecte adverse metabolice minime sau deloc, anumite dovezi ulterioare au ridicat problema unor astfel de efecte. În acest studiu am urmărit să evaluăm apariția acestor efecte adverse pe termen lung. Am realizat un studiu prospectiv asupra efectelor adverse metabolice ale indapamidei în cadrul Clinicii a V-a Medicină Internă Iași, România între 2016 și 2018. Treizeci de pacienți hipertensivi au fost monitorizați în ceea ce privește glicemia, uricemia și kaliemia înainte de începerea administrării indapamidei (T0), după minim trei luni de administrare (T1) şi după minim alte trei luni de întrerupere a administrării acesteia (T2). Am observat o creștere semnificativă a glicemiei şi uricemiei după administrarea indapamidei timp de trei luni, dar aceasta s-a redus, în majoritatea cazurilor, după oprirea tratamentului. A apărut, de asemenea, o scădere semnificativă a kaliemiei sub tratament, dar aceasta a fost reversibilă, după oprirea acestuia. Implicarea indapamidei în apariția hiperglicemiei, hiperuricemiei sau hipokaliemiei a fost sigură sau probabilă în opt cazuri și posibilă în cinci cazuri, conform algoritmului pentru evaluarea cauzalității OMS-UMC (2010). Diureticele înrudite cu tiazidele ar putea expune pacienții la aceleași riscuri metabolice ca și diureticele tiazidice. $\mathrm{O}$ administrare precaută ar putea fi protectivă, în cazul unei hipokaliemii deja existente. Este nevoie de studii mai ample pentru definirea dozei, perioadei de administrare și a altor factori asociați care ar putea duce la un risc crescut de efecte adverse.

Keywords: indapamide, side-effects, hyperglycaemia, hyperuricemia

\section{Introduction}

Since their development in the years 1950, thiazide diuretics have been the subject of great enthusiasm, but also of many controversies. These diuretics are effective antihypertensive medication, with plenty of evidence of clinical advantages and low cost. Thiazides, or more accurate "distal convoluted tubule diuretics", were obtained while testing derivatives of sulfonamide- based carbonic anhydrase inhibitors in order to discover drugs that enhance the excretion of sodium with chloride rather than sodium bicarbonate [1].

Thiazides very effectively reduce blood pressure, but the mechanisms involved are still subject of debate [2]. The thiazide-type (hydrochlorothiazide) and thiazidelike diuretics (chlorthalidone and indapamide) block the sodium chloride transporter in the distal tubule 
reducing sodium reabsorption. Their diuretic effect reduces the extracellular fluid and plasma volume, and so acutely decreases the cardiac output, but in chronic use the extracellular fluid returns to normal and vasodilation appears [3]. The mechanism by which thiazides dilate blood vessels is not completely defined yet, but it seems connected to the alteration of the ion flux in the vascular smooth muscle. Thiazides relax the vessels in vitro by opening large conductance, calcium-activated potassium channels, and so produce the hyperpolarization of the vascular smooth muscle cells [4]. They also induce mild vasodilation in vivo, related, at least in part, to the carbonic anhydraseinhibiting capacity of hydrochlorothiazide, which alkalinizes the cell [5]. Indapamide was proven to have a vasorelaxant effect similar to calcium channel antagonists [6, 7].

The preferred use of thiazide-type diuretics is based on more than 40 years of clinical trials, including active-controlled trials, which proved their efficacy (with some differences according to the endpoints) and clear benefits for the cardiovascular diseases (CVD): preventing rough clinical outcomes such as myocardial infarction, death, stroke, heart failure and renal failure $[8,9]$. Major concerns about their use appeared when their metabolic side-effects were described: hypokalaemia, impaired glucose tolerance, increased serum cholesterol and increased serum uric acid [10,11]. Evidence also showed that they can produce focal glomerular and tubular interstitial injury in rats, independent of their diuretic-induced hypokalaemia, hyperglycaemia, hyperuricemia and blood pressure changes [12].

Hyperglycaemia is most likely produced by hypokalaemia, yet it seems that non-renal effects of thiazides could be involved [10]. Thiazides may increase glycaemia by activating the renin-angiotensin-aldosterone system, possibly in connection with sympathetic activity, so that the hyperglycaemic effect of thiazides can be diminished by inhibiting the renin-angiotensinaldosterone axis, which also attenuates hypokalaemia $[10,13]$. Because of the proven benefits, hyperglycaemias is considered a small side effect which generally vanishes in time [10]. Thus, hydrochlorothiazide remains the most widely used diuretic in clinical practice. Yet the thiazide like diuretics have some proven advantages upon the thiazide-type ones: a longer half-life [8], a $12 \%$ additional risk reduction for cardiovascular events and a $21 \%$ additional reduction in heart failure $[9,14]$ and little or no metabolic sideeffects [14]. Some later evidence described adverse reactions of the thiazide-like diuretics $[8,9]$. In the present study we aimed to survey their side-effects in long term administration.

\section{Materials and Methods}

\section{Study design}

Because we have noticed some cases of very probable metabolic side effects for thiazide-like diuretics according to the WHO-UMC causality categories (WHO-UMC 2010) in the $\mathrm{V}^{\text {th }}$ Internal Medicine Clinic from the Railway Clinical Hospital in Iași, Romania, we conducted a pharmacovigilance study on some side-effects of indapamide in this clinic between January 2016 and January 2018. The approval from the Ethics Committee of the hospital was obtained. The inclusion criteria were: hypertensive patients aged between 40 and 90 , with an approximately equal number of males and females. They daily received as antihypertensive medication $1.5 \mathrm{mg}$ indapamide alone or in association with metabolically neutral antihypertensive (calcium channel blockers, angiotensin converting enzyme inhibitors or angiotensin receptor blockers). Some of the patients had associated pathologies, but none of them with influence on glycaemia, kaliemia, uricemia. We evaluated the glycaemia, kaliemia and uricemia in 34 hypertensive patients before starting the administration of indapamide (in the moment T0). The patients were asked to come back in the clinic after 3 months. Four patients ( 3 men and 1 woman) were lost in follow-up, so that in the moment T1 (after at least 3 months of administration of indapamide) only 30 patients remained: 15 men and 15 women. In the moment T1 indapamide was stopped and replaced with calcium channel blockers, inhibitors of angiotensine converting enzyme, or blockers of the angiotensine converting enzyme receptors. The patients were reevaluated three months after the withdrawal of indapamide (T2).

We have compared the glycaemia, uricemia and kaliemia for these patients in the moment T0 (before starting the treatment with indapamide) with the values found in the moment T1 (after 3 months of indapamide treatment), and then with the same data in the moment T2 (3 months after stopping the indapamide). The design of the study was thus an experiment which uses series of patients in time. In such studies each patient is his own control and compares the effect of a medication in time and, in this way, the effect of some native characteristics (e.g. age, gender, genetic factors) are eliminated from being confounding variables [15].

Statistical analysis

The data for the metabolic parameters were statistically analysed using the t-Test: Paired Two Sample for Means; we took into account as statistically significant the value for $\mathrm{p}<0.05$.

\section{Results and Discussion}

The 15 men aged between 45 and 77 years (mean age 67) had a body mass index (BMI) between $24.5 \mathrm{~kg} / \mathrm{m}^{2}$ and $41 \mathrm{~kg} / \mathrm{m}^{2}$ (mean $29.4 \mathrm{~kg} / \mathrm{m}^{2}$ ). The 15 women aged 
FARMACIA, 2020, Vol. 68, 5

between 45 and 85 years (mean age 64) had a BMI between $22.5 \mathrm{~kg} / \mathrm{m}^{2}$ and $41.5 \mathrm{~kg} / \mathrm{m}^{2}$ (mean $34.2 \mathrm{~kg} / \mathrm{m}^{2}$ ). A significant increase of glycaemia was found between the T0 and T1 moments $(92.73 \mathrm{mg} / \mathrm{dL})(119.2 \mathrm{mg} / \mathrm{dL})$ $(\mathrm{p}<0.001)$. The decrease of the medium values for glycaemia between T1 (119.2 mg/dL) and T2 (99.87 $\mathrm{mg} / \mathrm{dL})$ was also statistically significant $(\mathrm{p}<0.001)$.
The increase of glycaemia between T0 $(92.73 \mathrm{mg} / \mathrm{dL})$ and T2 (99.87 mg/dL) although statistically significant, is much smaller than the variations produced by the beginning and stopping the treatment with indapamide $(\mathrm{p}=0.0001$, Figures 1 and 2). Statistical significance of glucose levels at T0, T1 and T2 is represented in Table I.

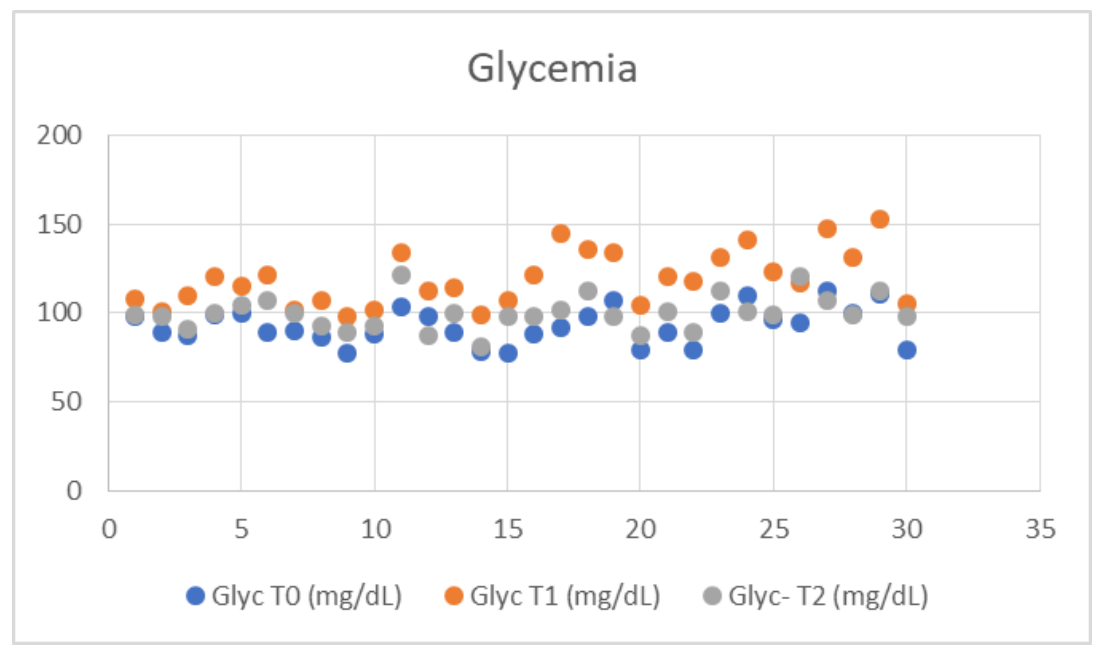

Figure 1.

Individual blood glucose levels at T0, T1 and T2

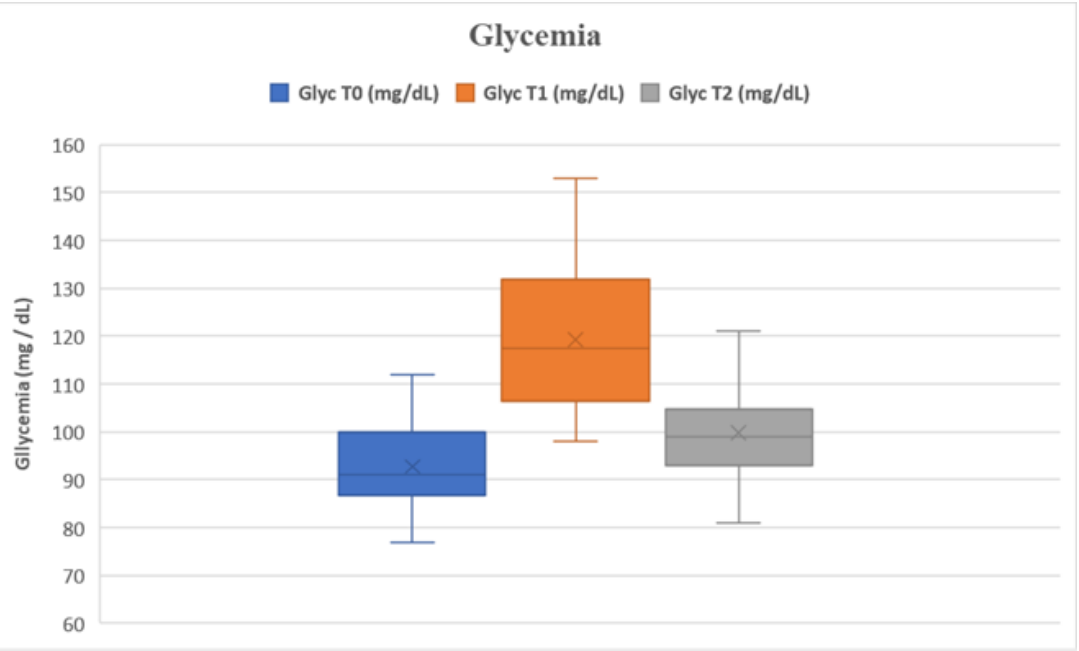

Figure 2.

Histogram of blood glucose levels at T0, T1 and T2

Table I

Statistical significance of glucose levels at T0, T1 and T2

\begin{tabular}{|c|c|c|c|}
\hline & Glyc T0 $(\mathrm{mg} d L)$ & Glyc $T 1(\mathrm{mg} / \mathrm{dL})$ & Glyc T2 $(\mathrm{mg} / \mathrm{dL})$ \\
\hline Mean & 92.733 & 119.2 & 99.867 \\
\hline Standard Deviation & 10.289 & 15.426 & 9.35 \\
\hline Standard Error & 1.878 & 2.816 & 1.707 \\
\hline T0 vs. T1 & \multicolumn{3}{|c|}{$<0.001$} \\
\hline T0 vs. T2 & $<0.001$ \\
\hline T1 vs. T2 & \multicolumn{3}{|c|}{$<0.001$} \\
\hline
\end{tabular}

At the T0 moment, before starting the treatment with indapamide, two patients had impaired fasting glucose (fasting plasma glucose level between 110 - $125 \mathrm{mg} / \mathrm{dL}$ ).
Seven patients had an impaired fasting glucose at the T1 moment, after indapamide administration, and nine of them had glycaemia over $126 \mathrm{mg} / \mathrm{dL}$ (suspicion 
FARMACIA, 2020, Vol. 68, 5

of type $2 \mathrm{DM})$. In the T2 moment, after having stopped the diuretic, none had values over $126 \mathrm{mg} / \mathrm{dL}$, so the possible diabetes was reversible, but five of them remained with a glycaemia in the range of 110 $125 \mathrm{mg} / \mathrm{dL}$ (with an impaired fasting glucose) and implicitly an increased risk of cardiovascular disease. A significant increase was noted for uric acid between T0 $(5.72 \mathrm{mg} / \mathrm{dL})$ and T1 $(7.33 \mathrm{mg} / \mathrm{dL})(\mathrm{p}<0.001)$.
The decrease of the values of uric acid between $\mathrm{T} 1$ $(7.33 \mathrm{mg} / \mathrm{dL})$ and T2 $(6.02 \mathrm{mg} / \mathrm{dL})(\mathrm{p}<0.001)$ and the difference for uric acid between moment T0 $(5.72$ $\mathrm{mg} / \mathrm{dL})$ and $\mathrm{T} 2(6.02 \mathrm{mg} / \mathrm{dL})(\mathrm{p}=0.03$, Figures 3 and 4) were also significant. Statistical significance of uric acid levels at $\mathrm{T} 0, \mathrm{~T} 1$ and $\mathrm{T} 2$ is represented in Table II.

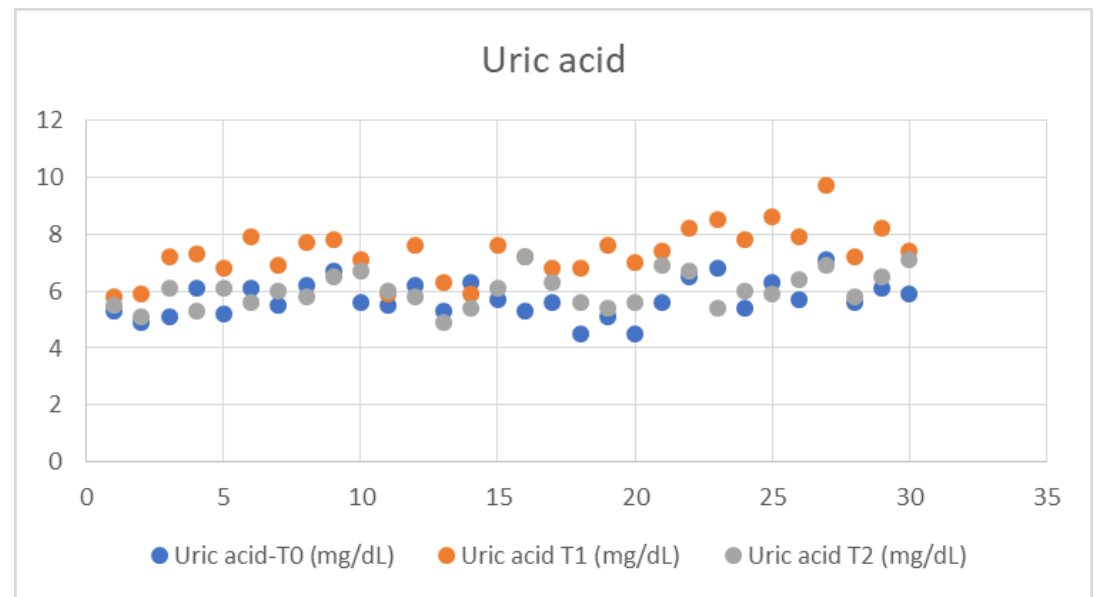

Figure 3.

Individual uric acid levels at T0, T1 and T2

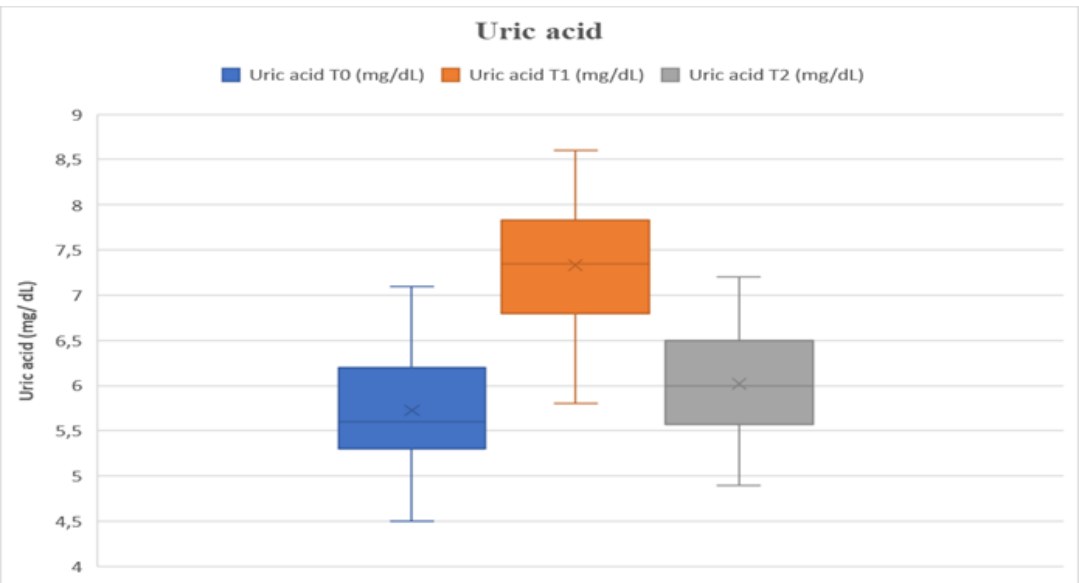

Figure 4.

Histogram of uric acid levels at T0, T1 and T2

Table II

Statistical significance of uric acid levels at T0, T1 and T2

\begin{tabular}{|c|c|c|c|}
\hline & Uric acid T0 $(\mathrm{mg} / \mathrm{dL})$ & Uric acid T1 $(\mathrm{mg} / \mathrm{dL})$ & Uric acid T2 $(\mathrm{mg} / \mathrm{dL})$ \\
\hline Mean & 5.723 & 7.333 & 6.02 \\
\hline Standard Deviation & 0.636 & 0.878 & 0.601 \\
\hline Standard Error & 0.116 & 0.1603 & 0.109 \\
\hline T0 vs. T1 & \multicolumn{3}{|c|}{$<0.001$} \\
\hline T0 vs. T2 & $<0.05$ \\
\hline T1 vs. T2 & $<0.001$ \\
\hline
\end{tabular}

A significant decrease of kaliemia was noted between T0 (4.05 mEq/L) and T1 (3.54 mEq/L) $(\mathrm{p}<0.001)$, and a significant increase between $\mathrm{T} 1(3.54 \mathrm{mEq} / \mathrm{L})$ and T2 $(3.997 \mathrm{mEq} / \mathrm{L})(\mathrm{p}<0.001)$. The decrease of kaliemia between T0 (4.05 mEq/L) and T2 (3.997 $\mathrm{mEq} / \mathrm{L}$ ) was not significant $(\mathrm{p}=0.41$, Figures 5 and $6)$. Statistical significance of potassium levels at $\mathrm{T} 0, \mathrm{~T} 1$ and $\mathrm{T} 2$ is represented in Table III. 


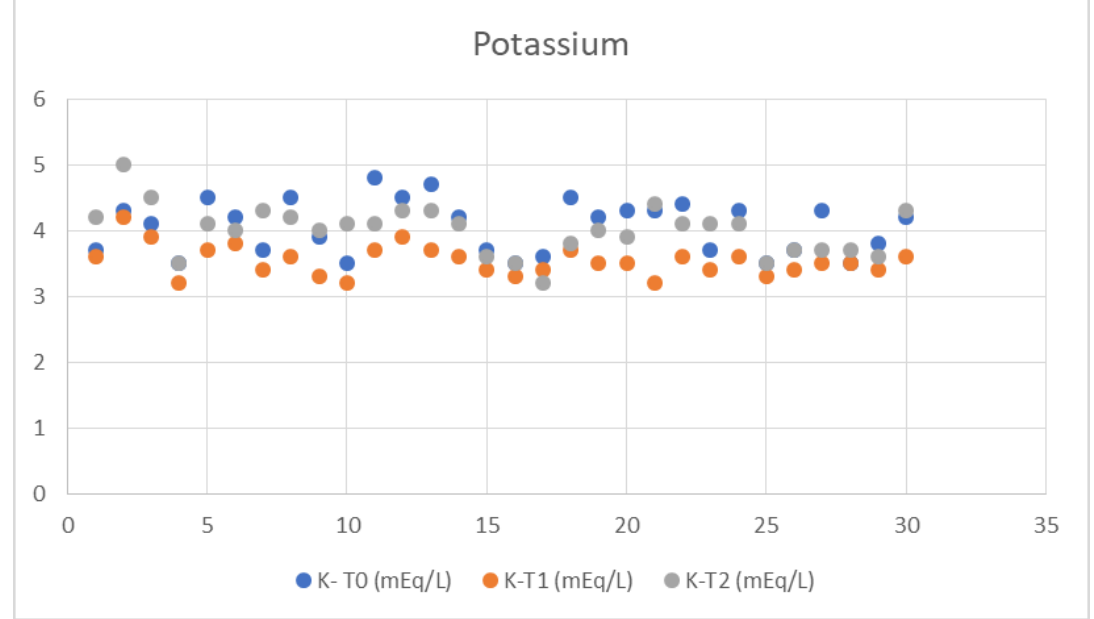

Figure 5.

Individual potassium levels at $\mathrm{T} 0, \mathrm{~T} 1$ and $\mathrm{T} 2$

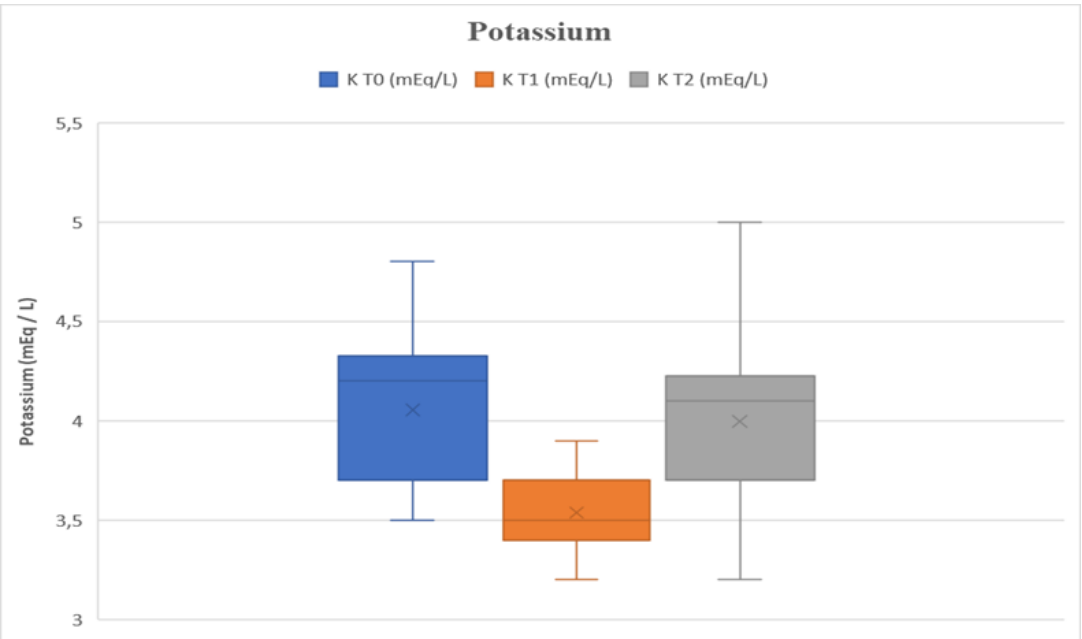

Figure 6.

Histogram of potassium levels at $\mathrm{T} 0, \mathrm{~T} 1$ and $\mathrm{T} 2$

Table III

Statistical significance of potassium levels at T0, T1 and T2

\begin{tabular}{|c|c|c|c|}
\hline & Potassium T0 $(\mathrm{mEq} / \mathrm{L})$ & Potassium T1 $(\mathrm{mEq} / \mathrm{L})$ & Potassium T1 $(\mathrm{mEq} / \mathrm{L})$ \\
\hline Mean & 4.053 & 3.537 & 3.997 \\
\hline Standard Deviation & 0.404 & 0.229 & 0.369 \\
\hline Standard Error & 0.0738 & 0.0419 & 0.0674 \\
\hline T0 $v$ s. T1 & \multicolumn{3}{|c|}{$<0.001$} \\
\hline T0 $v$ s. T2 & \multicolumn{3}{|c|}{$>0.05$} \\
\hline T1 $v s$. T2 & $<0.001$ \\
\hline
\end{tabular}

The Pearson product-moment correlation coefficient (r) was used in order to evaluate the relation between the dose of indapamide with the modifications of glycaemia, uricemia and kaliemia. The straight correlations were high for glycaemia $(r=0.7732)$ and mild for uricemia $(r=0.3998)$; a very weak reverse correlation was found for kaliemia $(r=-0.01510)$.

The results prove a significant increase of glycaemia and uricemia in time under the administration of indapamide, which disappeared in most of the cases after stopping the treatment. A significant decrease of kaliemia was noted during the treatment, also reversible after stopping indapamide. The incrimination of indapamide in producing hyperglycaemia, hyperuricemia or hypokalaemia was certain or probable in eight cases and possible in five cases according to the WHO-UMC (2010) algorithm for causality assessment [16-18]. Using these diagnostic criteria other factors that could have influenced modifications of glycaemia, uricemia, kaliemia (eg. alcohol, diet, smoking, stress, infections) [19] were eliminated. Three patients have experienced all the three side-effects, and five of them experienced two of those. Thus, we incriminated the use of thiazide-like diuretics in producing hyper- 
glycaemia, hyperuricemia and hypokalaemia. Larger studies are needed in order to bring further evidence and describe the incrimination of other possible associated risk factors [20].

\section{Conclusions}

Thiazide-like diuretics may expose to the same metabolic risks as thiazide-type diuretics. Precautious administration in case of already present hypokalaemia could be protective. Larger studies are needed in order to define the dose and the period of administration of the thiazide-like diuretics which may become dangerous and may expose to the risk of sideeffects.

\section{Conflict of interest}

The authors declare no conflict of interest.

\section{References}

1. Ellison DH, Loffing $\mathbf{J}$, Thiazide effects and adverse effects insights from molecular genetics. Hypertension, 2009; 54: 196-202.

2. Hughes AD, How do thiazide and thiazide-like diuretics lower blood pressure. J Renin Angiotensin Aldosterone Syst., 2004; 5: 155-160.

3. Pecker MS, Pathophysiologic effects and strategies for long-term diuretic treatment of hypertension. In: Laragh JH, Brenner BM, eds. Hypertension: Pathophysiology, Diagnosis, and Management. New York, NY: Raven Press; 1990: 2143-2168.

4. Pickkers P, Hughes AD, Relaxation and decrease in $\left[\mathrm{Ca}^{2+}\right]$ by hydrochlorothiazide in guinea-pig isolated mesenteric arteries. Br J Pharmacol., 1995; 114: 703707.

5. Pickkers P, Garcha RS, Schachter M, Smits P, Hughes AD. Inhibition of carbonic anhydrase accounts for the direct vascular effects of hydrochlorothiazide. Hypertension, 1999; 33: 1043-1048.

6. Roush GC, Sica DA, Diuretics for hypertension: a review and update. Am J Hypertens., 2016; 29: 11301137.

7. Waeber B, Rotaru C, Feihl F, Position of indapamide, a diuretic with vasorelaxant activities, in antihypertensive therapy. Exp Opin Pharmacother., 2012; 13: 15151526.

8. Maghiar F, Vicaș LG, Ardelean A, Teușdea A, Țica OA, Oros C, Mureșan ME, Retrospective study on angiotensin-converting-enzyme inhibitors treatment. Farmacia, 2020; 68(1): 90-96.
9. Olde Engberink RH, Frenkel WJ, van den Bogaard B, Brewster LM,Vogt L, van den Born BJ, Effects of thiazide-type and thiazide-like diuretics on cardiovascular events and mortality: systematic review and meta-analysis. Hypertension, 2015; 65: 1033-1040.

10. Carter BL, Einhorn PT, Brands M, He J, Cutler JA, Whelton PK, Bakris GL, Brancati FL, Cushman WC, Oparil S, Wright JTJr, Working Group from the National Heart, Lung, and Blood Institute, Thiazideinduced dysglycemia: call for research from a working group from the national heart, lung, and blood institute. Hypertension, 2008; 52(1): 30-36.

11. Zillich AJ, Garg J, Basu S, Bakris GL, Carter BL, Thiazide diuretics, potassium, and the development of diabetes: a quantitative review. Hypertension, 2006; 48: 219-224.

12. Reungjui $\mathrm{S}, \mathrm{Hu} \mathrm{H}, \mathrm{Mu} \mathrm{W}$, Roncal CA, Croker BP, Patel JM, NakagawaT, Srinivas T, Byer K, Simoni J, Wesson D, Sitprija V, Johnson RJ, Thiazide-induced subtle renal injury not observed in states of equivalent hypokalemia. Kidney Int., 2007; 72: 1483-1492.

13. Barbu RM, Gavrilescu CM, Paraschiv C, Popescu IR, Bild W, Influence of angiotensin upon uterine smooth muscle. Med Surg J., 2019; 123(2): 43-53.

14. Roush GC, Ernst ME, Kostis JB, Tandon S, Sica DA, Head-to-head comparisons of hydrochlorothiazide with indapamide and chlorthalidone: antihypertensive and metabolic effects. Hypertension, 2015; 65: 10411046.

15. Hulley SB, Cummings SR, Browner WR, Grady DC, Newman TB, Designing clinical research, $4^{\text {th }}$ Edition, Philadelphia, by Lippincott Williams \& Wilkins, 2013; 85-96, 192-206.

16. Varallo FR, Planeta CS, Herdeiro MT, de Carvalho Mastroianni P, Imputation of adverse drug reactions: Causality assessment in hospitals. PLOS ONE, 2017; 12(2): 1-10.

17. World Health Organization Collaborating Centre for International Drug Monitoring, the Uppsala Monitoring Centre (WHO-UMC). The use of the WHO-UMC system for standardised case causality assessment 2010, www.who.int

18. Zaki SA, Adverse drug reaction and causality assessment scales. Lung India, 2011; 28(2): 152-153.

19. Crișan-Dabija R, Mihăescu T, Interstitial lung diseases misdiagnosis: a Healthcare Improvement Science (HIS) approach. Eur Respir J., 2019; 52(62): PA2983.

20. Gavrilescu CM, Felea MG, Barbu R, Duma O, Bodescu MM, Ghiuru R, Boerescu C, Paraschiv C, Assessement of adverse drug reactions as cardiovascular risk factors. Med Surg J., 2016; 120(1): 48-54. 